\title{
Analysis of cloud condensation nuclei composition and growth kinetics using a pumped counterflow virtual impactor and aerosol mass spectrometer
}

\author{
J. G. Slowik ${ }^{1, *}$, D. J. Cziczo ${ }^{2}$, and J. P. D. Abbatt ${ }^{1}$ \\ ${ }^{1}$ University of Toronto, Department of Chemistry, 80 St. George St., Toronto, ON, M5S 3H6, Canada \\ ${ }^{2}$ Pacific Northwest National Laboratory, Atmospheric Science and Global Change Division, 902 Battelle Blvd, \\ Richland, Washington, USA \\ *now at: Paul Scherrer Institut, 5232 Villigen PSI, Switzerland
}

Received: 31 December 2010 - Published in Atmos. Meas. Tech. Discuss.: 17 January 2011

Revised: 19 July 2011 - Accepted: 28 July 2011 - Published: 30 August 2011

\begin{abstract}
We present a new method of determining the size and composition of $\mathrm{CCN}$-active aerosol particles. Method utility is illustrated through a series of ambient measurements. A continuous-flow thermal-gradient diffusion chamber (TGDC), pumped counterflow virtual impactor (PCVI), and Aerodyne time-of-flight mass spectrometer (AMS) are operated in series. Ambient particles are sampled into the TGDC, where a constant supersaturation is maintained, and $\mathrm{CCN}$-active particles grow to $\sim 2.5 \pm 0.5 \mu \mathrm{m}$. The output flow from the TGDC is directed into the PCVI, where a counterflow of dry $\mathrm{N}_{2}$ gas opposes the particle-laden flow, creating a region of zero axial velocity. This stagnation plane can only be traversed by particles with sufficient momentum, which depends on their size. Particles that have activated in the TGDC cross the stagnation plane and are entrained in the PCVI output flow, while the unactivated particles are diverted to a pump. Because the input gas is replaced by the counterflow gas with better than $99 \%$ efficiency at the stagnation plane, the output flow consists almost entirely of dry $\mathrm{N}_{2}$ and water evaporates from the activated particles. In this way, the system yields an ensemble of $\mathrm{CCN}$-active particles whose chemical composition and size are analyzed using the AMS. Measurements of urban aerosol in downtown Toronto identified an external mixture of $\mathrm{CCN}$-active particles consisting almost entirely of ammonium nitrate and ammonium sulfate, with $\mathrm{CCN}$-inactive particles of the same size consisting of a mixture of ammonium nitrate, ammonium sulfate, and organics. We also discuss results from the first field deployment of the TGDC-PCVI-AMS system, conducted from
\end{abstract}

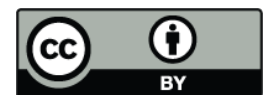

Correspondence to: J. G. Slowik (jay.slowik@psi.ch)
mid-May to mid-June 2007 in Egbert, Ontario, a semirural site $\sim 80 \mathrm{~km}$ north of Toronto influenced both by clean air masses from the north and emissions from the city. Organicdominated particles sampled during a major biogenic event exhibited higher CCN activity and/or faster growth kinetics than urban outflow from Toronto, despite the latter having a higher inorganic content and higher O:C ratio. During both events, particles were largely internally mixed.

\section{Introduction}

The action of submicron aerosol particles as cloud condensation nuclei (CCN) has been well established as an important negative climate forcing (Twomey et al., 1984; Albrecht, 1989; Solomon et al., 2007). The magnitude of this cooling effect remains poorly understood and constitutes a major uncertainty in the climate system (IPCC, 2007). Cloud properties are influenced by a complex array of factors, including the number of $\mathrm{CCN}$-active particles in an air parcel. In general, increased $\mathrm{CCN}$ concentrations lead to clouds that are more reflective (Twomey, 1977) and have longer lifetimes due to the inhibition of precipitation (Albrecht, 1989; Liou and $\mathrm{Ou}, 1989$ ).

The ability of particles to act as $\mathrm{CCN}$ is determined by particle size and composition (Köhler, 1936). Laboratory studies have shown that aerosol CCN activity can be predicted accurately for particles of known composition (see for example Cruz and Pandis, 1997; Raymond and Pandis, 2002, 2003; Bilde and Svenningsson, 2004; Broekhuizen et al., 2004; Abbatt et al., 2005). However, the complex mixtures of inorganic and organic compounds found in ambient particles

Published by Copernicus Publications on behalf of the European Geosciences Union. 
present a more difficult challenge (Saxena and Hildemann, 1996; Jacobson et al., 2000). In particular, uncertainties exist in the characterization of the organic fraction and the ensemble mixing state.

For ambient particles, analyses of $\mathrm{CCN}$ properties broadly fall into two classes: (1) generation of water droplets from ambient aerosol under controlled supersaturation conditions, coupled to particle size and composition measurements by means of a theoretical framework (e.g. Köhler Theory); and (2) direct measurement of the composition of ambient cloud particles. An example of the first analysis class is the CCN closure study (e.g. Conant et al., 2004; Broekhuizen et al., 2006; Chang et al., 2007, 2010; Medina et al., 2007; Lance et al., 2009). In this method, measured particle size and composition are used together with Köhler Theory to predict the number of $\mathrm{CCN}$-active particles in sampled air. The predicted $\mathrm{CCN}$ concentrations are compared to measured concentrations by a CCN counter at a selected supersaturation. Assumptions regarding component properties (e.g. hygroscopicity or surface tension of organics) are varied to test closure between modeled and measured CCN concentrations. An alternate example of this class of study is the measurement of droplet growth kinetics at a fixed supersaturation; the effect of (separately-measured) chemical composition on the particle hygroscopicity parameter $(\kappa)$ (Petters and Kreidenweis, 2007) and the mass accommodation coefficient of water to the particle can be inferred by modeling the growth process (e.g. Shantz et al., 2003, 2010; Ruehl et al., 2008; Lance et al., 2009; Ruehl et al., 2009). This approach has the advantage of controlled activation conditions, but requires combining disparate $\mathrm{CCN}$ number, particle number/size and particle composition measurements, as well as a variety of estimates and assumptions within the theoretical framework.

A second class of experiments focuses on the direct measurement of the composition of particles that have acted as $\mathrm{CCN}$ in the atmosphere. This typically involves (1) collection of cloudwater followed by offline chemical analysis (e.g. Parungo et al., 1982; Collett et al., 2002; Decesari et al., 2005; Hutchings et al., 2009) or (2) in situ sampling of cloud droplets followed by isolation of these droplets from the interstitial aerosol using a counterflow virtual impactor (CVI), evaporation of water from the droplet, and chemical analysis of the residual (e.g. Ogren et al., 1985; Noone et al., 1988; Heintzenberg et al., 1996; Twohy and Gandrud, 1998; Cziczo et al., 2003; Kamphus et al., 2010). This approach has the advantage that the chemical and physical properties of $\mathrm{CCN}$-active particles are directly measured; however, the conditions under which the particles originally activated are not well constrained. Further, aerosol scavenging by cloud droplets means that the residual may not fully reflect the composition of the $\mathrm{CCN}$ prior to cloud formation.

The technique introduced in this paper complements the approaches described above. Particles are activated in a CCN chamber under controlled conditions. The cloud particles are inertially separated and dried in a counterflow virtual impactor (CVI), allowing direct measurement of the CCN size and composition by online instrumentation. This approach combines controlled activation conditions with direct measurements of the composition of the $\mathrm{CCN}$-active particle fraction. Measurements of this type are only now possible with the recent development of a pumped CVI (PCVI) (Boulter et al., 2006; Kulkarni et al., 2011) and online aerosol mass spectrometry techniques. The TGDC-PCVI-AMS technique yields quantitative mass spectra and chemically-resolved size distributions of $\mathrm{CCN}$-active ambient particles.

\section{Experimental}

The TGDC-PCVI-AMS system consists of a thermal gradient diffusion chamber (TGDC), a pumped counterflow virtual impactor (PCVI), and a time-of-flight aerosol mass spectrometer connected in series, as shown in Fig. 1. The details of these system components are discussed in the following sections, and a brief overview of the integrated system is presented here. Laboratory validation of a related PCVI-based system (using a different $\mathrm{CCN}$ chamber and different detection scheme) is available in the literature (Hiranuma et al., 2011). Ambient particles are sampled into the CCN chamber and exposed to a controlled supersaturation $(0.33 \%$ in the current study). The $\mathrm{CCN}$-active fraction forms cloud droplets, which grow to several microns in diameter. The particle flow is then passed through the PCVI, which separates the particles based on their momentum. Larger particles (i.e. the activated cloud droplets) pass through the PCVI, while the smaller (non-activated) particles are pumped away. The PCVI also replaces the humidified air in the particle flow with filtered, dry air. In this flow, water evaporates from the cloud droplets, leaving only the original particle.

During normal sampling, the TGDC-PCVI-AMS system alternated between two modes. In the first mode (" $\mathrm{CCN}$ active"), the system operates as shown in Fig. 1. This mode yields quantitative mass spectra and mass distributions of the $\mathrm{CCN}$-active aerosol fraction. In the second mode ("polydisperse"), the AMS samples directly from the atmosphere, bypassing the TGDC and PCVI. This mode yields the overall aerosol composition and mass distributions. During normal sampling, the two modes were alternated, with each mode having a sampling period of $\sim 20 \mathrm{~min}$.

The supersaturation $(0.33 \%)$ was chosen to facilitate comparison with previous measurements at Egbert $(0.32 \%$ by Chang et al., 2007) and concurrent CCN measurements during this campaign $(0.42 \%$ by Chang et al., $2010,0.35 \%$ by Shantz et al., 2010). Additionally, initial tests of the TGDCPCVI-AMS system suggested that this supersaturation enhanced operation by increasing the fraction of $\mathrm{CCN}$-active particles that form cloud droplets with diameters greater than the PCVI size cutoff. This (1) increases the number of sampled particles, presently a limitation of the technique, and 


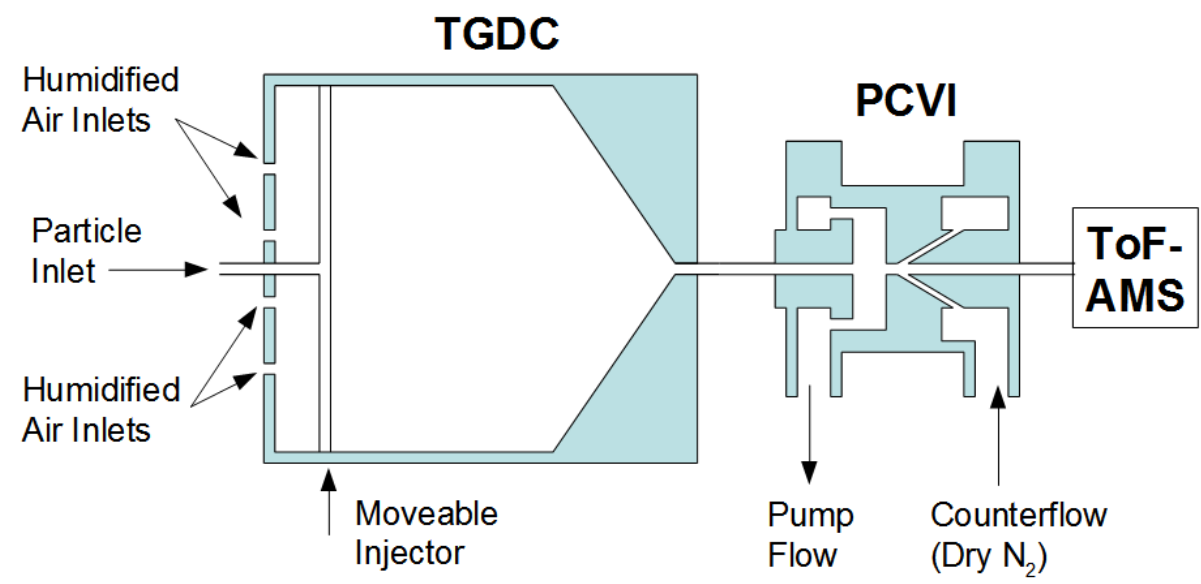

Fig. 1. Schematic diagram of the TGDC-PCVI-AMS system (not to scale).

(2) reduces the effect of droplet growth rates on the particles sampled at the maximum residence time, facilitating data interpretation.

\subsection{Thermal gradient diffusion chamber}

The thermal gradient diffusion chamber has previously been described in detail (Pradeep Kumar et al., 2003). The chamber consists of two horizontally-mounted copper plates separated by a $1.3 \mathrm{~cm}$ Teflon spacer. The plates are covered with moist filter paper, which is periodically re-wetted through holes drilled in the top plate. The temperatures of each plate are individually controlled by water from two recirculating baths passing through copper tubing soldered to the outside of each plate. The top plate is maintained at a slightly higher temperature than the lower plate, resulting in a linear temperature gradient between the plates. The combination of this linear temperature gradient with the exponential dependence of the saturation water vapor pressure on temperature generates a region of supersaturaton on the center line of the chamber. The lower plate is set $\sim 2{ }^{\circ} \mathrm{C}$ above room temperature to prevent evaporation between the chamber exit and the sampling instrumentation.

Particles enter the chamber through the movable injector shown in Fig. 1. The particle flow is surrounded by a humidified sheath flow. The sheath-to-particle flow ratio is maintained at 9:1 (sheath flow rate $=1.81 \mathrm{~min}^{-1}$; particle flow rate $=0.21 \mathrm{~min}^{-1}$ ). Unless otherwise specified, the TGDC was operated with the injector pulled back to yield the maximum residence time. Based on chamber volume and flow rate, the average residence time is calculated to be $\sim 20 \mathrm{~s}$, but because the particles are entrained at the center of a laminar flow, actual residence time is $\sim 10 \mathrm{~s}$. This position was utilized for normal operation because it yielded the maximum $\mathrm{CCN}$ concentrations.

The supersaturation in the TGDC is determined from calibration with size-selected $\left(\mathrm{NH}_{4}\right)_{2} \mathrm{SO}_{4}$ particles (Pradeep Kumar et al., 2003) as follows. An aerodynamic particle sizer
(APS) is connected to the TGDC exit flow, and a condensation particle counter (CPC) is operated in parallel to the chamber. In this configuration, the APS measures the number of cloud droplets (defined as particles with diameters greater than $\sim 2.5 \pm 0.5 \mu \mathrm{m}$ ) and the CPC measures the total number of particles entering the chamber. The activated fraction (APS counts/CPC counts) is measured as a function of particle size for a selected combination of upper and lower plate temperatures. The activation diameter is defined as the diameter at which $50 \%$ of the particles activate and is used to calculate the supersaturation in the TGDC using Kohler Theory. For the present study, the supersaturation was set to $\sim 0.33 \%$.

\subsection{Pumped counterflow virtual impactor}

The pumped counterflow virtual impactor (PCVI) used in this study has been previously described in the literature (Boulter et al., 2006; Hiranuma et al., 2011; Kulkarni et al., 2011) and deployed in the field for direct measurement of ice nuclei (Cziczo et al., 2003; DeMott et al., 2003), and only a brief overview of its operation is presented here. In the PCVI, the humidified, particle-laden flow is opposed by a dry $\mathrm{N}_{2}$ flow. These opposing flows generate a region of zero axial velocity at their intersection, termed the stagnation plane. Only particles with sufficient inertia are able to cross the plane to be entrained in the exit flow leading to the sampling instrumentation. Smaller particles are removed in the pump flow.

The PCVI provides an enhancement in the particle concentration which is theoretically equal to the ratio of input to output flows. In the present study, a PCVI enhancement factor of 20 is expected; in practice, a maximum transmission of up to $\sim 50 \%$ of the theoretical maximum was observed. This transmission was measured by introducing $\mathrm{NH}_{4} \mathrm{NO}_{3}$ particles with mobility diameter $=350 \mathrm{~nm}$ into the TGDCPCVI-AMS system. A supersaturation and residence time were chosen such that the entire cloud droplet distribution 
consisted of sizes larger than the PCVI cutpoint. This was confirmed by an aerodynamic particle sizer inserted between the TGDC and PCVI, which also yielded the number concentration of particles entering the PCVI. The AMS, which detects $350 \mathrm{~nm} \mathrm{NH} \mathrm{NO}_{3}$ particles with $\sim 100 \%$ efficiency, was used to determine the number concentration of transmitted particles. In a second set of experiments, the AMS was replaced with a CPC, which sampled with a diluted flow to preserve the flow conditions within the PCVI. These two tests both indicated that the PCVI operated at $\sim 50 \%$ of its ideal transmission. This transmission is somewhat lower that the value of $\sim 85 \%$ reported during the initial testing of the PCVI (Boulter et al., 2006). Possible causes for the difference include differing flow dynamics caused by the lower total PCVI flow rates in the present experiment, or differences in spacing and/or alignment of the PCVI input and collection orifices (Kulkarni et al., 2011).

The PCVI was set to yield a size cut of $\sim 2-3 \mu \mathrm{m}$ aerodynamic diameter. The cutpoint was empirically confirmed as follows. $\mathrm{NH}_{4} \mathrm{NO}_{3}$ particles were produced by atomization, size-selected (mobility diameter $=200 \mathrm{~nm}$ ), and introduced into the TGDC. The $\mathrm{NH}_{4} \mathrm{NO}_{3}$ particles activate and the resulting size distribution of cloud droplets was measured by an APS. The mode diameter of this distribution was controlled by varying the supersaturation and residence time within the TGDC. A CPC was installed at the PCVI outlet, and the ratio of CPC counts to APS counts (normalized to the measured PCVI maximum transmission, i.e. enhancement by a factor of 10) was used to estimate the effective cutpoint by assuming larger sizes are preferentially transmitted. For example, a normalized CPC/APS ratio of 0.4 indicates that the largest $40 \%$ of particles were being transmitted; this value would then be used together with the APS size distribution to estimate the cutpoint. Calibrations were performed using a set of 3 distributions having mode diameters at $\sim 2 \mu \mathrm{m}, \sim 3 \mu \mathrm{m}$, and $\sim 4 \mu \mathrm{m}$. Additionally, size-selected $\mathrm{NH}_{4} \mathrm{NO}_{3}$ particles with mobility diameter $\leq \sim 700 \mathrm{~nm}$ (the maximum diameter tested) yielded zero transmission. The PCVI cutpoint was set by adjusting the pump and counterflow flowrates. Flowrates used to achieve the $\sim 2.5 \mu \mathrm{m}$ PCVI cutpoint were as follows: inlet flow (from TGDC) $\sim 2.01 \mathrm{~min}^{-1}$, pump flow $\sim 2.71 \mathrm{~min}^{-1}$, counterflow $\left(\mathrm{N}_{2}\right) \sim 0.51 \mathrm{~min}^{-1}$, and output flow (to AMS) $\sim 0.11 \mathrm{~min}^{-1}$. Note that the flow balance in the PCVI is as follows: input flow + counterflow $=$ output flow + pump flow. The relationship of the counterflow to the input and pump flows is expected to affect the location of the stagnation plane within the PCVI, but does not greatly affect gas transmission. For an ideal device, setting counterflow $=$ output flow yields zero transmission of sampled ambient gas. In practice, counterflow/output flow ratios of up to $\sim 3$ were required to remove better than $99 \%$ of the ambient gas (Boulter et al., 2006). In the present system, a ratio of 5 is used (counterflow $=0.51 \mathrm{~min}^{-1}$ vs. output flow $=0.11 \mathrm{~min}^{-1}$ ).

\subsection{Aerosol mass spectrometer}

The Aerodyne time-of-flight aerosol mass spectrometer (C-ToF-AMS) has previously been described in detail (Drewnick et al., 2005). Particles are sampled at atmospheric pressure through a $100 \mu \mathrm{m}$ critical orifice into an aerodynamic lens. The lens has the dual purpose of focusing the particles into a narrow beam and accelerating them to a velocity inversely related to their vacuum aerodynamic diameter. Particles pass through a vacuum chamber $\left(\sim 10^{-7}\right.$ torr $)$ and impact on a resistively heated surface $\left(600^{\circ} \mathrm{C}\right)$ where they flash vaporize. The resulting gas plume is ionized by electron impact $(70 \mathrm{eV})$ and the ions are detected by a timeof-flight mass spectrometer. The AMS alternates between two modes of operation. In the first mode, the particle beam is alternately blocked and unobstructed, yielding a difference mass spectrum of the incident particles. In the second mode, the particle beam is intersected by a spinning chopper wheel $(1 \%$ duty cycle, $150 \mathrm{~Hz})$. Particle time-of-flight is measured between the chopper and the detector, yielding velocity and thus vacuum aerodynamic diameter. Because the mass spectrometer sampling rate $(50 \mathrm{kHz})$ is much higher than the chopper frequency, this operating mode yields sizeresolved particle mass spectra, which can also be interpreted as chemically-resolved mass distributions. Calibration and quantification procedures for the AMS are described elsewhere (Allan et al., 2003a).

\subsection{Sampling locations}

The TGDC-PCVI-AMS system was deployed in two locations: downtown Toronto and Egbert, Ontario. Sampling in downtown Toronto was performed from the second floor of the Lash Miller Chemical Laboratories from 4-6 December 2007. Particle transmission lines consisted of 0.25 inch outer diameter copper tubing.

Sampling at Egbert was performed during the Egbert 2007 field campaign (14 May to 15 June 2007), at the Center for Atmospheric Research Experiments (CARE), Egbert, ON, Canada. Details of the Egbert 2007 campaign are provided elsewhere (Vlasenko et al., 2009; Chan et al., 2010; Chang et al., 2010; Shantz et al., 2010; Slowik et al., 2010). Egbert is located in a rural area approximately $70 \mathrm{~km}$ north of Toronto. During the Egbert 2007 campaign, influences on the site included (1) southerly winds bringing polluted outflow from the heavily populated Toronto area and Southern Ontario and (2) northerly winds bringing a biogenic aerosol formed from terpene emissions by forested regions to the north/northeast. Identification of these periods and chemical characterization of the aerosol is discussed in Slowik et al. (2010).

\section{Results and discussion}

In this section, we focus discussion on three sampling periods: (1) aerosol sampled in downtown Toronto during 

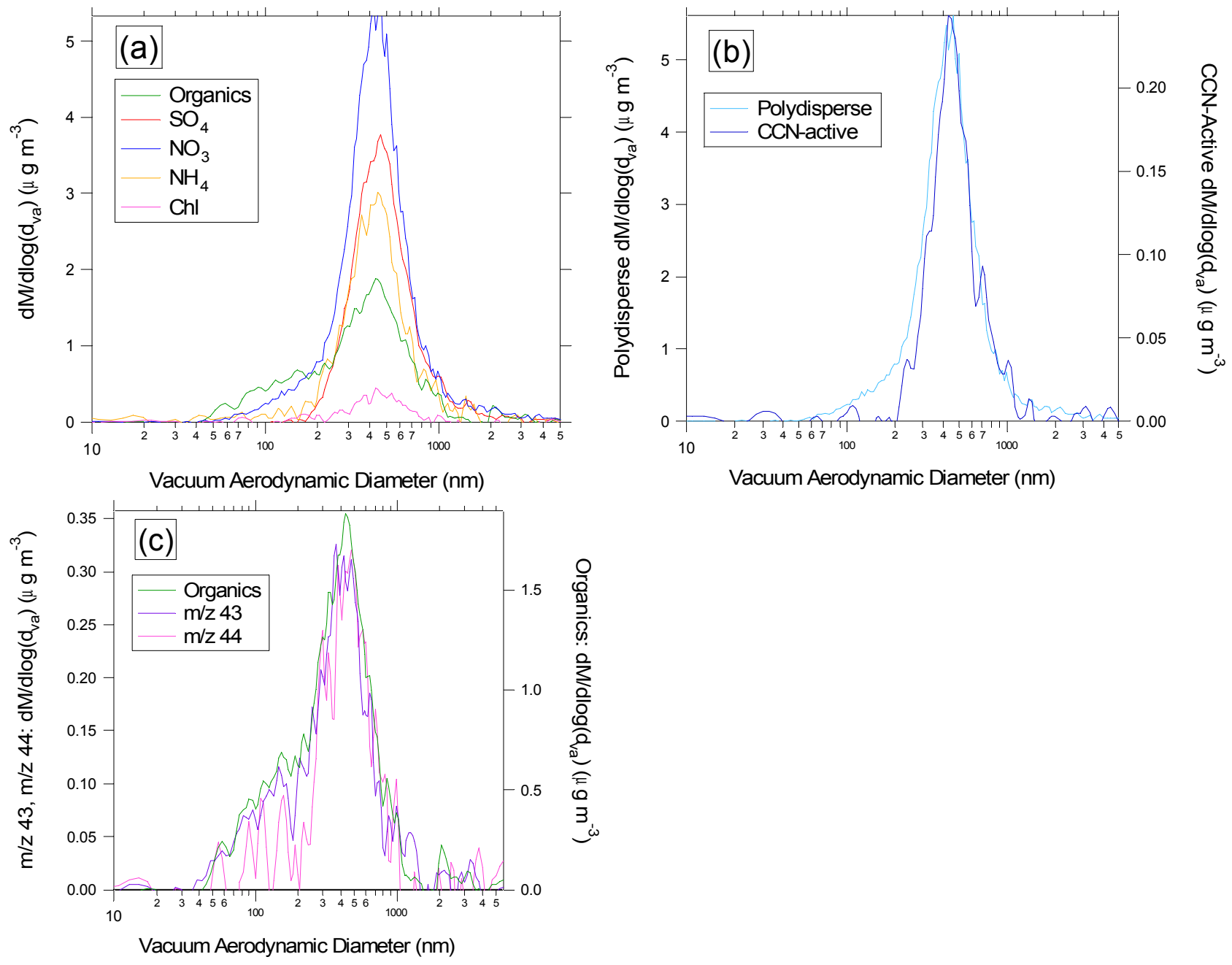

Fig. 2. AMS mass distributions from the downtown Toronto case study. Figure 2a shows the polydisperse distributions for organic and inorganic components. Figure $2 \mathrm{~b}$ compares the polydisperse and $\mathrm{CCN}$-active mass distributions for the nitrate component of the aerosol. Figure $2 \mathrm{c}$ shows the polydisperse mass distributions for $m / z 43\left(\mathrm{C}_{2} \mathrm{H}_{3} \mathrm{O}^{+}, \mathrm{C}_{3} \mathrm{H}_{7}^{+}\right), m / z 44\left(\mathrm{CO}_{2}^{+}\right)$, and total organics.

December 2007; (2) urban outflow and (3) biogenic SOA sampled at Egbert during the Egbert 2007 field campaign. Identification and characterization of the urban outflow and biogenic SOA case study periods are discussed in detail elsewhere (Slowik et al., 2010). Characteristics of the case studies are discussed below, with a focus on comparing the polydisperse aerosol (i.e. sampled directly from ambient) and the $\mathrm{CCN}$-active fractions (i.e. sampled through by the TGDCPCVI-AMS system).

\subsection{Case study: downtown Toronto}

Figure 2 shows mass distributions recorded in downtown Toronto for polydisperse aerosol and the $\mathrm{CCN}$-active fraction, detected by the AMS and TGDC-PCVI-AMS, respectively. Figure 2a shows the ambient polydisperse size distributions for organics, sulfate, nitrate, ammonium, and chloride. Figure $2 \mathrm{~b}$ compares the polydisperse and $\mathrm{CCN}$-active size distributions for nitrate. A more detailed look at the sizedependent organic composition is presented in Fig. 2c, where mass distributions are shown for the total organics, $m / z 43$ $\left(\mathrm{C}_{2} \mathrm{H}_{3} \mathrm{O}^{+}, \mathrm{C}_{3} \mathrm{H}_{7}^{+}\right)$and $m / z 44\left(\mathrm{CO}_{2}^{+}\right)$. In Fig. 2a, the organic distribution has two distinct modes: $d_{\mathrm{va}} \sim 150 \mathrm{~nm}$ and $d_{\mathrm{va}} \sim$ $450 \mathrm{~nm}$. Such a multimodal distribution indicates that particles are externally mixed and is characteristic of an urban setting. The smaller mode is typically due to local primary emissions (e.g. from traffic) (Allan et al., 2003b), while the larger mode is composed of more aged, regional aerosol.

The external mixture evident from the organic size distributions is also reflected in the nitrate trace. The nitrate distribution is monomodal (mode $d_{\mathrm{va}} \sim 450 \mathrm{~nm}$ ). However, a tail in the distribution is evident at smaller sizes. Such a tail is clearly not present in the sulfate distribution. The nitrate tail probably results from the condensation of locally-generated ammonium nitrate onto preexisting particles, in this case the 
small traffic mode. Condensation occurs onto both the traffic and accumulation modes. In Fig. 2b, the tail appears in the polydisperse nitrate mass distribution, but not in the CCNactive distribution. This indicates that on exposure to supersaturated water vapor, the traffic mode particles either (1) do not form cloud particles or (2) form cloud particles, but with a diameter below the size cutoff of the PCVI $(\sim 2-3 \mu \mathrm{m})$. The CCN-active organic mass distribution is not shown because the signal-to-noise renders the distribution below the detection limit. (Note that the mass distributions are collected in particle time-of-flight mode, which requires the use of a $1 \%$ chopper and size-resolved particle mass spectra; see Sect. 2.3. Because of the lower duty cycle and the need to segregate mass spectra by size, this operating mode is less sensitive than the difference mass spectra used to determine overall particle composition, discussed below.) Due to the short residence time in the $\mathrm{CCN}$ chamber (maximum $\sim 10 \mathrm{~s}$ ), significant scavenging of small particles by cloud droplets is not expected.

System detection limits vary considerably with the aerosol composition. This is especially true for the organic fraction. While no systematic study of the organic detection limit was conducted, the following examples are instructive. For the hydrocarbon-rich aerosol in downtown Toronto, organic mass distributions could not be resolved even after $\sim 2 \mathrm{~h}$ of integration at organic mass concentrations of $6.2 \mu \mathrm{g} \mathrm{m}^{-3}$. In contrast, more oxygenated aerosol sampled at the Egbert site yielded organic mass distributions above detection limit for organic mass concentrations of $2.6 \mu \mathrm{g} \mathrm{m}^{-3}$ and $\sim 1 \mathrm{~h}$ of integration. Regardless of composition, $\sim 1 \mathrm{~h}$ of integration was sufficient to yield mass spectra for organic concentrations below $1 \mu \mathrm{g} \mathrm{m}^{-3}$.

Tables 1 and 2 show the composition of polydisperse aerosol and the $\mathrm{CCN}$ active fraction for the all three case studies. In downtown Toronto, these tables show the CCNactive fraction to be chemically distinct from the polydisperse aerosol. An important difference is the decreased organic mass fraction in the $\mathrm{CCN}$-active particles $(0.21 \pm 0.08)$ relative to the polydisperse aerosol $(0.33 \pm 0.05)$. A corresponding increase is observed for the inorganic component mass fractions in the $\mathrm{CCN}$-active aerosol, particularly for sulfate (mass fraction $=0.20 \pm 0.04$ for polydisperse, $0.28 \pm 0.06$ for $\mathrm{CCN}$-active). Further, the $\mathrm{CCN}$-active organics are much more oxygenated than the polydisperse aerosol ( $\mathrm{CCN}$-active $\mathrm{O}: \mathrm{C}$ ratio is $\sim 0.52$ versus $\sim 0.21$ for polydisperse). Figure $2 \mathrm{c}$ shows that $m / z 44$, which acts as a tracer for oxygenated organics (Aiken et al., 2008), is nearly absent in the small organic mode. The increased oxygenation of the $\mathrm{CCN}$-active mode therefore suggests that these particles correspond to the larger mode in Fig. 2. Correspondingly, the data suggest that the smaller mode is CCNinactive, which is consistent with expectations for an urban environment. In such an environment, the smaller diameter and hydrocarbon-like composition of the small mode are consistent with primary anthropogenic emissions (e.g. traf-

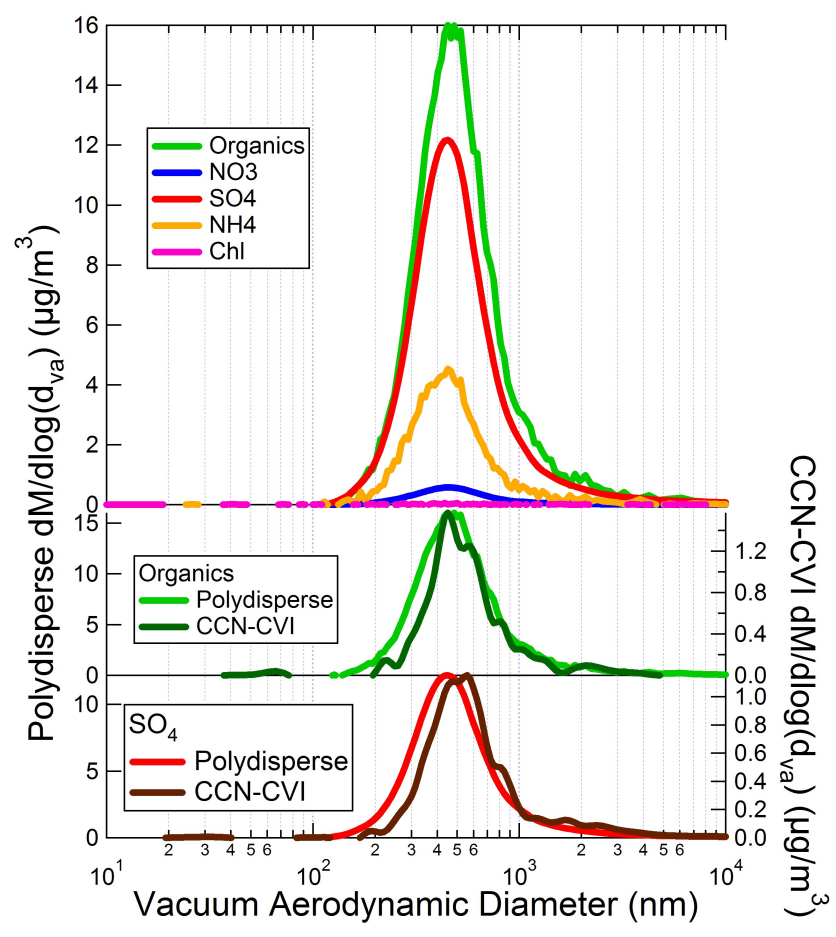

Fig. 3. AMS mass distributions for the Egbert urban outflow case study period. Ambient polydisperse and $\mathrm{CCN}$-active distributions are plotted on the left and right axes, respectively. The top panel shows the polydisperse particle composition, while the bottom two panels show comparisons of polydisperse and $\mathrm{CCN}$-active distributions for organics and sulfate.

fic particles) (e.g. Allan et al., 2003b; Zhang et al., 2005). Results from several CCN closure studies indicate that such particles are not $\mathrm{CCN}$-active (Broekhuizen et al., 2006; $\mathrm{Cu}$ bison et al., 2008; Quinn et al., 2008; Chang et al., 2010).

\subsection{Case studies: urban outflow and biogenic SOA at Egbert, Ontario}

The upper panels in Figs. 3 and 4 show polydisperse mass distributions for organics, sulfate, nitrate, ammonium, and chloride as measured during the Egbert 2007 field campaign. The lower panels compare polydisperse and $\mathrm{CCN}-$ active mass distributions for organic and sulfate. As discussed in Sect. 2.4, this study was conducted from mid-May to mid-June at a semirural site $\sim 60 \mathrm{~km}$ north of Toronto. Data in Fig. 3 were acquired during 24 May 2007, 11:15 to 18:20, when the Egbert site was influenced by urban outflow from Toronto. Data in Fig. 4 were collected during 12 June 2007, 10:45 to 17:35, when the site was influenced by a major biogenic aerosol event originating in the boreal forests of northern Ontario and Quebec (Slowik et al., 2010).

The distributions in Figs. 3 and 4 are in all cases monomodal, suggesting a largely internally mixed aerosol. This is consistent with expectations, given that the field site 
Table 1. Summary of polydisperse aerosol composition during case study periods. Uncertainties represent one standard deviation of measurements collected during the case study period. O:C ratios are estimated from the $m / z$ 44-to-organics ratio using the empirical relationship determined by Aiken et al. (2008).

\begin{tabular}{lrrr}
\hline & Downtown Toronto & Toronto Outflow & Biogenic Aerosol \\
\hline Total AMS mass & $8.54 \pm 2.93$ & $32.0 \pm 1.1$ & $13.6 \pm 0.4$ \\
$\left(\mu \mathrm{g} \mathrm{m}^{-3}\right)$ & & & \\
Organics/AMS mass & $0.33 \pm 0.05$ & $0.49 \pm 0.04$ & $0.78 \pm 0.04$ \\
$\mathrm{SO}_{4} /$ AMS mass & $0.20 \pm 0.04$ & $0.37 \pm 0.03$ & $0.14 \pm 0.03$ \\
$\mathrm{NO}_{3} /$ AMS mass & $0.27 \pm 0.04$ & $0.02 \pm 0.002$ & $0.02 \pm 0.001$ \\
$\mathrm{NH}_{4} /$ AMS mass & $0.19 \pm 0.01$ & $0.12 \pm 0.01$ & $0.05 \pm 0.01$ \\
$m / z$ 44/Organics & $0.033 \pm 0.004$ & $0.131 \pm 0.006$ & $0.106 \pm 0.002$ \\
$m / z$ 43/Organics & $0.023 \pm 0.002$ & $0.074 \pm 0.001$ & $0.097 \pm 0.002$ \\
Approx. O:C ratio & 0.21 & 0.58 & 0.48 \\
\hline
\end{tabular}

Table 2. Summary of CCN-active aerosol composition during case study periods. Uncertainties represent one standard deviation of measurements collected during the case study period. O:C ratios are estimated from the $m / z$ 44-to-organics ratio using the empirical relationship determined by Aiken et al. (2008).

\begin{tabular}{lrrr}
\hline & Downtown Toronto & Toronto Outflow & Biogenic Aerosol \\
\hline $\begin{array}{l}\text { Total AMS mass } \\
\left(\mu \mathrm{g} \mathrm{m}^{-3}\right)\end{array}$ & $0.33 \pm 0.39$ & $2.68 \pm 2.53$ & $0.63 \pm 0.27$ \\
Organics/AMS mass & $0.21 \pm 0.08$ & $0.50 \pm 0.04$ & $0.75 \pm 0.02$ \\
$\mathrm{SO}_{4} /$ AMS mass & $0.28 \pm 0.06$ & $0.32 \pm 0.09$ & $0.16 \pm 0.03$ \\
$\mathrm{NO}_{3} /$ AMS mass & $0.31 \pm 0.06$ & $0.02 \pm 0.002$ & $0.03 \pm 0.005$ \\
$\mathrm{NH}_{4} /$ AMS mass & $0.19 \pm 0.05$ & $0.16 \pm 0.06$ & $0.07 \pm 0.03$ \\
$m / z$ 44/Organics & $0.114 \pm 0.017$ & $0.123 \pm 0.008$ & $0.102 \pm 0.006$ \\
$m / z$ 43/Organics & $0.080 \pm 0.008$ & $0.069 \pm 0.004$ & $0.094 \pm 0.003$ \\
Approx. O:C ratio & 0.52 & 0.55 & 0.47 \\
\hline
\end{tabular}

is removed from major primary emissions sources. Internally mixed particles were also observed using a PCVI-based system in Richland, Washington, USA, utilizing a different CCN chamber and different mass spectrometers (Hiranuma et al., 2011). Tables 1 and 2 show that the composition of the polydisperse aerosol and the $\mathrm{CCN}$-active fraction are the same within measurement uncertainty for both the urban outflow and biogenic SOA case study periods.

For the urban outflow period, the $\mathrm{CCN}$-active particle component is shifted to larger sizes than the polydisperse distribution (see Fig. 3, middle and lower panels). This indicates that in the urban outflow, some fraction of particles with $d_{\mathrm{va}} \sim 200$ to $300 \mathrm{~nm}$ either (1) do not activate or (2) activate but do not grow large enough to be classified as cloud droplets in the PCVI. Based on other CCN measurements conducted during the Egbert 2007 campaign, the critical activation diameter at $0.33 \%$ supersaturation is less than $100 \mathrm{~nm}$ mobility diameter (Chang et al., 2010; Shantz et al., 2010). The higher $\mathrm{CCN}$ activity and/or faster droplet growth rates for biogenic SOA relative to urban outflow are consistent with direct measurements of droplet growth rates during the campaign (Shantz et al., 2010). Shantz et al. (2010) measured droplet growth rates for biogenic SOA that were comparable to $\left(\mathrm{NH}_{4}\right)_{2} \mathrm{SO}_{4}$ particles of the same size and number concentration; however, urban outflow particles yielded a slower growth rate relative to $\left(\mathrm{NH}_{4}\right)_{2} \mathrm{SO}_{4}$. TGDC-PCVIAMS experiments in which the residence time in the TGDC (i.e. $\mathrm{CCN}$ chamber) was varied also illustrate the influence of droplet growth kinetics on TGDC-PCVI-AMS measurements, as discussed in Sect. 3.3.

In contrast to the Toronto outflow (Fig. 3), during the biogenic period (Fig. 4) the $\mathrm{CCN}$-active distribution is not shifted relative to the polydisperse aerosol. This suggests that the biogenic aerosol does not experience the limitations on cloud droplet activation and/or growth exhibited by the urban outflow particles. That is, the biogenic particles activate more readily and/or grow more quickly than those in the urban outflow. Interestingly, this behavior occurs despite the polydisperse biogenic particles containing a smaller inorganic fraction $(0.22 \pm 0.04$ for biogenic SOA vs. $0.51 \pm 0.04$ for urban outflow, see Table 1$)$ and a lower $\mathrm{O}: \mathrm{C}$ ratio $(0.58$ for urban outflow vs. 0.48) (see Tables 1 and 2). (Recall that the 


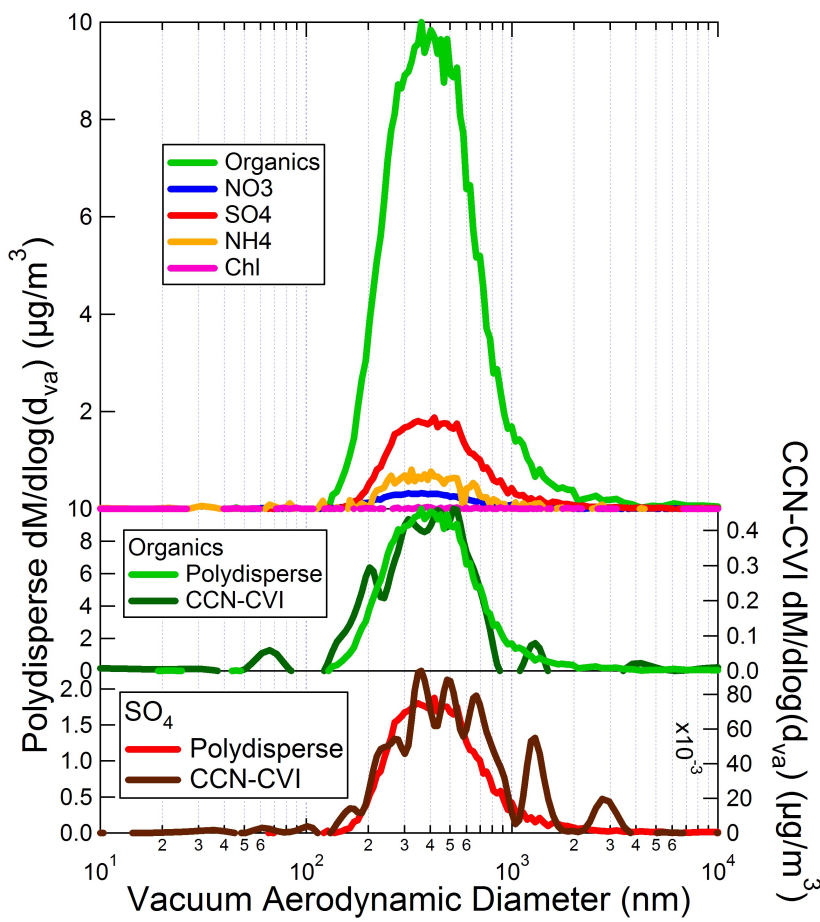

Fig. 4. AMS mass distributions for the Egbert biogenic SOA case study period. Ambient polydisperse and $\mathrm{CCN}$-active distributions are plotted on the left and right axes, respectively. The top panel shows the polydisperse particle composition, while the bottom two panels show comparisons of polydisperse and $\mathrm{CCN}$-active distributions for organics and sulfate.

composition of the polydisperse and $\mathrm{CCN}$-active fraction is indistinguishable.) CCN activity would usually be expected to increase with both the inorganic fraction (Petters et al., 2007, and references therein) and O:C ratio (Duplissy et al., 2011).

Further, the lower $\mathrm{CCN}$ activity of aerosol in the urban outflow relative to biogenic SOA is not due to differences in particle size between the case studies. Figure 5 shows the polydisperse mass distributions of organics for these two periods. The urban outflow aerosol is shifted towards larger sizes. If differences in $\mathrm{CCN}$ activity during these periods were governed by particle size, aerosol in the urban outflow would be expected to be more $\mathrm{CCN}$-active than biogenic SOA. However, the opposite trend is observed instead.

The decreased CCN activity in the urban outflow particles may arise from the internal particle structure, perhaps with the particles containing a coating of hydrophobic organics. More specifically, the oxygenated and inorganic components of the urban outflow particles originate in large part from beyond the Toronto urban centre, e.g. from power plant emissions in the Ohio Valley and sources throughout heavily populated southern Ontario. However, they also contain a significant fraction of hydrocarbon-like organics, which likely originate from the Toronto region. Condensation of fresh hydro- carbons on a preexisting particle would result in a hydrophobic layer on the particle exterior, slowing $\mathrm{CCN}$ activation and growth. Model simulations of droplet growth kinetics during the Egbert study support this possibility (Shantz et al., 2010). Kinetic inhibition of $\mathrm{CCN}$ and hygroscopic growth has also previously been observed in polluted and marine environments (Johnson et al., 2005; Ruehl et al., 2008, 2009). In several of these studies, the observed inhibition was attributed to a condensed hydrophobic film (Johnson et al., 2005; Ruehl et al., 2009).

As shown in Tables 1 and 2, the case study periods show no detectable difference between the chemical composition of the $\mathrm{CCN}$-active and polydisperse aerosol. This is consistent with an internally-mixed aerosol, implied by the monomodal size distributions in Figs. 3 and 4. However, it also indicates that the particle-to-particle variations in composition do not significantly alter their ability to act as CCN at the selected supersaturation $(0.33 \%)$.

\subsection{Effect of droplet kinetics}

Further evidence of the increased CCN activity of biogenic SOA relative to urban outflow is evident from experiments in which the residence time in the $\mathrm{CCN}$ chamber was varied. These experiments were performed using the TGDC movable injector described in Sect. 2.1 (see also Fig. 1). In Fig. 6, we compare mass distributions obtained at the normal (and maximum) residence time of $\sim 10 \mathrm{~s}$ with distributions obtained at the minimum residence time $(\sim 3 \mathrm{~s})$ for the urban outflow and biogenic SOA case studies. The figure shows that decreasing the residence time, i.e. by moving the injector from the "out" to "in" positions (see Fig. 1), causes a decrease in the $\mathrm{CCN}$-active mass during both case study periods. However, the decrease is proportionally larger for the urban outflow period.

As discussed in section 2, the classification of a particle as "CCN-active" by the TGDC-PCVI-AMS is operational in nature. To observe activation, it is required that a particle (1) form a cloud droplet and (2) grow such that the diameter exceeds $\sim 2.5 \mu \mathrm{m}$. Decreasing the residence time makes these conditions more difficult to satisfy, because a particle must activate earlier and/or grow faster to exceed the $\sim 2.5 \mu \mathrm{m}$ cutpoint. Therefore the stronger decrease observed for the urban outflow particles relative to biogenic SOA indicates that the urban particles are less $\mathrm{CCN}$-active in a kinetic sense. This is consistent with the observations discussed in Sect. 3.2.

In the TGDC-PCVI-AMS system, it is not possible to distinguish between the effects of early/late activation and slow/fast droplet growth. However, as in Sect. 3.2 we can assign the effects to chemical composition rather than particle size. For the distributions in Fig. 6a and b, no significant biases in size for the $\mathrm{CCN}$-active particles relative to the polydisperse distribution are observed. This indicates that the ability of a particle to activate and/or grow quickly enough to exceed the PCVI size cut does not strongly depend on the 

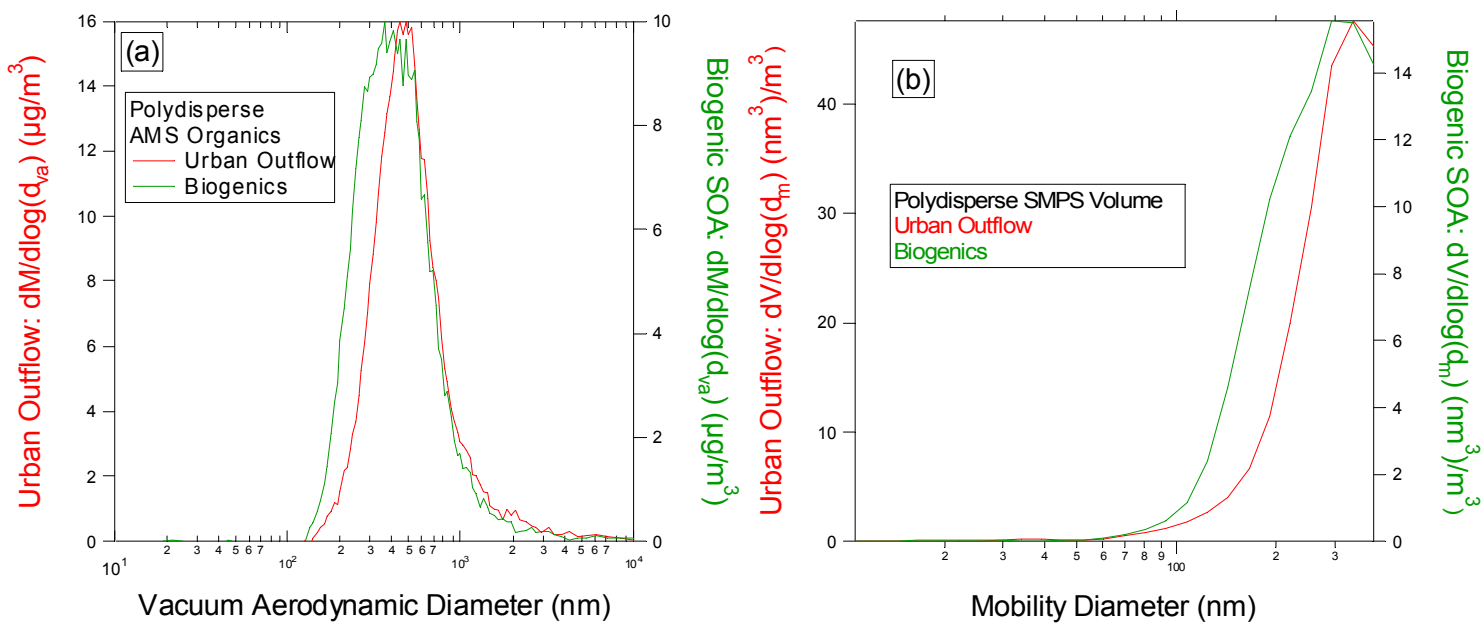

Fig. 5. Comparison of polydisperse size distributions for the Egbert urban outflow and biogenic case study periods. Figure 5a shows organic mass distributions and Fig. 5b shows SMPS volume distributions.
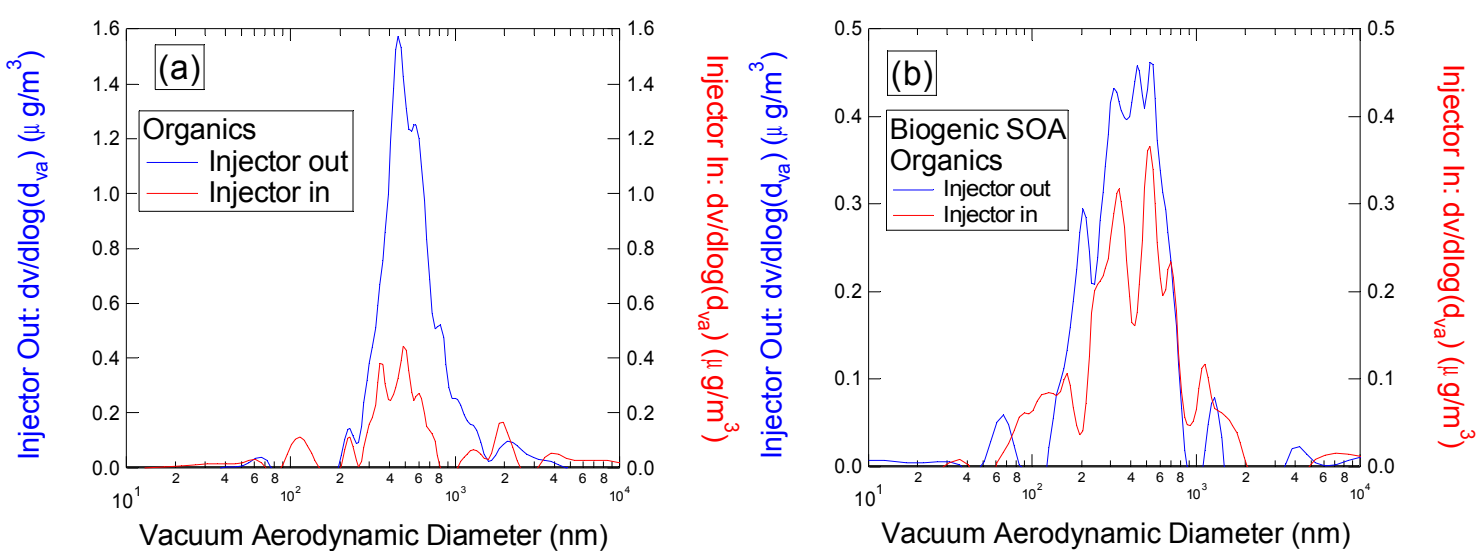

Fig. 6. Residence time experiments for the urban outflow (a) and biogenic SOA (b) case studies. Organic mass distributions are shown for the minimum (injector "in") and maximum (injector "out") TGDC residence times.

size of the original particle. Observed differences in $\mathrm{CCN}$ activation and/or droplet growth between the urban outflow and biogenic SOA aerosol are therefore attributed to chemical differences.

\subsection{Effect of AMS collection efficiency}

The AMS mass measurement requires vaporization of particles impinging on the vaporizer surface. However, some fraction of particles instead bounce off the surface and are not detected. The fraction of detected particles, defined as the bounce collection efficiency $\left(E_{\mathrm{b}}\right)$, depends primarily on particle phase (Matthew et al., 2008). Because particles travelling through the TGDC-PCVI-AMS system are likely to undergo changes in phase due to the induced delicquescence/CCN activation/efflorescence cycle, the influence of $E_{\mathrm{b}}$ on the system measurements is briefly discussed below.
Ambient particle measurements have typically yielded $E_{\mathrm{b}} \sim 0.5$, with larger values observed under the following conditions: (1) high mass fraction of ammonium nitrate, (2) acidic sulfate aerosol, (3) relative humidity $>90 \%$. Laboratory experiments have also shown that organic liquid coatings increase collection efficiency. However, enhancement of collection efficiency by organic liquid has not been demonstrated in ambient data to date. Rather, a recent study shows $E_{\mathrm{b}}$ to be unaffected by organic content (Middlebrook et al., 2011). This is consistent with recent evidence suggesting that many organics may exist in the atmosphere in a glasslike state, rather than as liquids (Zobrist et al., 2008).

Parameterizations for estimating collection efficiency based on ammonium nitrate content and sulfate acidity can be found in the literature (Middlebrook et al., 2011; Matthew et al., 2008; Crosier et al., 2007; Quinn et al., 2006). For the TGDC-PCVI-AMS system, such corrections would need to be applied independently to the measured polydisperse 
and $\mathrm{CCN}$-active composition. In the present study, chemical differences between the bulk polydisperse and $\mathrm{CCN}$ active particle ensembles are insufficient to introduce an $E_{\mathrm{b}}$-based bias.

Relative humidity effects are potentially more complicated. Because the PCVI output flow is dried by replacement of the humid air with dry air at the stagnation plane, the $\mathrm{CCN}$-active distribution is expected to have a collection efficiency of $\sim 0.5$, similar to typical results for dried ambient particles, except for the types of particle composition described above. In theory, one could also dry the input flow to the TGDC-PCVI-AMS, as has been previously done to simplify estimation of $E_{\mathrm{b}}$ in some other AMS measurement campaigns. However, in the TGDC-PCVI-AMS system, the possibility exists that such drying could introduce artifacts into the polydisperse/CCN-active comparison by changing the phase of the input aerosol, thereby altering the cloud formation process. As discussed in the manuscript, the nature of the TGDC-PCVI-AMS system means that droplet growth kinetics affect which particles are classified as "cloud droplets".

Because of these issues, sample flow was not dried in the present study and the polydisperse $E_{\mathrm{b}}$ was instead estimated using two methods: (1) correlation of single particle mass spectra with optical scattering pulses from a light scattering module incorporated into the AMS, providing a direct measure of $E_{\mathrm{b}}$ for particles with mobility diameters larger than $\sim 215 \mathrm{~nm}$; and (2) comparison with SMPS measurements. These measurements agreed within uncertainties, yielding an estimatd $E_{\mathrm{b}}$ of $0.6+/ 0.1$ (Slowik et al., 2010). The similarity of this value to the typical dry values $E_{\mathrm{b}}(\sim 0.5)$, coupled with the lack of compositional changes in $\mathrm{CCN}$-active particle modes (i.e. excluding the small $\mathrm{CCN}$-inactive mode observed in downtown Toronto), suggests that $E_{\mathrm{b}}$ does not cause significant biases in the present study. (Although optical scattering/single particle measurements were made for both the $\mathrm{CCN}$-active and polydisperse distributions, the number of sampled $\mathrm{CCN}$-active particles was too low for the measurement to be useful in constraining $E_{\mathrm{b}}$.)

Although $E_{\mathrm{b}}$ is not expected to cause significant bias to the comparison of $\mathrm{CCN}$-active and polydisperse aerosol in the present study, this may be in part a result of the composition and mixing state of the sampled aerosol and it is possible that $E_{\mathrm{b}}$ could affect measurements at a different location. This issue can be addressed by $E_{\mathrm{b}}$-constraining measurements, such as the optical scattering/single particle measurements described above and/or by integration of other instruments into the TGDC-PCVI system.

\section{Conclusions}

A novel method for real-time detection of the size and composition of $\mathrm{CCN}$-active aerosol was developed and successfully deployed at urban and semirural sites. The method consists of a parallel plate $\mathrm{CCN}$ chamber, a pumped counterflow virtual impactor (PCVI) and a time-of-flight aerosol mass spectrometer (C-ToF-AMS) operated in series. The CCN chamber grows $\mathrm{CCN}$-active particles into droplets larger than $1 \mu \mathrm{m}$, the PCVI inertially selects these large particles and dries them, and the AMS detects the non-refractory component. During deployment in downtown Toronto, the TGDCPCVI-AMS system demonstrated the ability to resolve a $\mathrm{CCN}$-active accumulation mode from an external mixture with a $\mathrm{CCN}$-inactive traffic particle mode. At a semirural site north of Toronto, the TGDC-PCVI-AMS indicated that particles were mostly internally mixed. Comparison of measurements during a period of Toronto outflow and a major biogenic event indicated that the biogenic particles were more CCN active and/or grew to larger cloud droplet sizes despite having a lower mass fraction of inorganics and less oxygenated organics. This effect may be due to deposition of a hydrophobic layer on preexisting particles passing through Toronto on their way to the sampling location (Shantz et al., 2010).

Acknowledgements. This work was supported by the Canadian Foundation for Climate and Atmospheric Sciences through the Cloud-Aerosol Feedbacks and Climate Network and by the Natural Science and Engineering Research Council (Canada). The authors also thank Environment Canada for hosting the Egbert 2007 field campaign at the Centre for Atmospheric Research Experiments (CARE), Egbert, Ontario.

Edited by: D. Toohey

\section{References}

Abbatt, J., Broekhuizen, K., and Kumar, P.: Cloud condensation nucleus activity of internally mixed ammonium sulfate/organic acid particles, Atmos. Environ., 39, 4767-4778, 2005.

Aiken, A. C., DeCarlo, P. F., Kroll, J. H., Worsnop, D. R., Huffman, J. A., Docherty, K. S., Ulbrich, I. M., Mohr, C., Kimmel, J. R., Sueper, D., Sun, Y., Zhang, Q., Trimborn, A., Northway, M., Ziemann, P. J., Canagaratna, M. R., Onasch, T. B., Alfarra, M. R., Prevot, A. S. H., Dommen, J., Duplissy, J., Metzger, A., Baltensperger, U., and Jimenez, J. L.: O/C and OM/OC Ratios of Primary, Secondary, and Ambient Organic Aerosols with HighResolution Time-of-Flight Aerosol Mass Spectrometry, Environ. Sci. Technol., 42, 4478-4485, doi:10.1021/es703009q, 2008.

Albrecht, B. A.: Aerosols, cloud microphysics, and fractional cloudiness, Science, 245, 1227-1230, 1989.

Allan, J. D., Jimenez, J. L., Williams, P. I., Alfarra, M. R., Bower, K. N., Jayne, J. T., Coe, H., and Worsnop, D. R.: Quantitative Sampling using an Aerodyne Aerosol Mass Spectrometer 1: Techniques of Data Interpretation and Error Analysis, J. Geophys. Res., 108, 4090, doi:10.1029/2002JD002358, 2003a.

Allan, J. D., Alfarra, M. R., Bower, K. N., Williams, P. I., Gallagher, M. W., Jimenez, J. L., McDonald, A. G., Nemitz, E., Canagaratna, M. R., Jayne, J. T., Coe, H., and Worsnop, D. R.: Quantitative sampling using an Aerodyne aerosol mass spectrometer 2. Measurements of fine particulate chemical composition in two UK cities, J. Geophys. Res., 108, 4091, doi:10.1029/2002JD002359, 2003b. 
Bilde, M. and Svenningsson, B.: CCN activation of slightly soluble organics: The importance of small amounts of inorganic salt and particle phase, Tellus B, 56, 128-134, 2004.

Boulter, J. E., Cziczo, D. J., Middlebrook, A. M., Thomson, D. S., and Murphy, D. M.: Design and Performance of a Pumped Counterflow Virtual Impactor, Aerosol Sci. Technol., 40, 969976, 2006.

Broekhuizen, K., Kumar, P., and Abbatt, J. P. D.: Partially soluble organics as cloud condensation nuclei: Role of trace soluble and surface active species, Geophys. Res. Lett., 31, L01107, doi:10.1029/2003GL018203, 2004.

Broekhuizen, K., Chang, R.Y.-W., Leaitch, W. R., Li, S.-M., and Abbatt, J. P. D.: Closure between measured and modeled cloud condensation nuclei $(\mathrm{CCN})$ using size-resolved aerosol compositions in downtown Toronto, Atmos. Chem. Phys., 6, 2513-2524, doi:10.5194/acp-6-2513-2006, 2006.

Chan, T. W., Huang, L., Leaitch, W. R., Sharma, S., Brook, J. R., Slowik, J. G., Abbatt, J. P. D., Brickell, P. C., Liggio, J., Li, S.M., and Moosmüller, H.: Observations of OM/OC and specific attenuation coefficients (SAC) in ambient fine PM at a rural site in central Ontario, Canada, Atmos. Chem. Phys., 10, 2393-2411, doi:10.5194/acp-10-2393-2010, 2010.

Chang, R. Y.-W., Liu, P. S. K., Leaitch, W. R., and Abbatt, J. P. D.: Comparison between measured and predicted $\mathrm{CCN}$ concentrations at Egbert, Ontario: Focus on the organic aerosol fraction at a semi-rural site, Atmos. Environ., 41, 8172-8182, 2007.

Chang, R. Y.-W., Slowik, J. G., Shantz, N. C., Vlasenko, A., Liggio, J., Sjostedt, S. J., Leaitch, W. R., and Abbatt, J. P. D.: The hygroscopicity parameter $(\kappa)$ of ambient organic aerosol at a field site subject to biogenic and anthropogenic influences: relationship to degree of aerosol oxidation, Atmos. Chem. Phys., 10, 50475064, doi:10.5194/acp-10-5047-2010, 2010.

Collett, J. L., Bator, A., Sherman, D. E., Moore, K. F., Hoag, K. J., Demoz, B. B., Rao, X., and Reilly, J. E.: The chemical composition of fogs and intercepted clouds in the United States, Atmos. Res., 64, 29-40, 2002.

Conant, W. C., VanReken, T. M., Rissman, T. A., Varutbangkul, V., Jonsson, H. H., Nenes, A., Jimenez, J. L., Delia, A. E., Bahreini, R., Roberts, G. C., Flagan, R. C., and Seinfeld, J. H.: Aerosolcloud drop concentration closure in warm cumulus, J. Geophys. Res.-Atmos., 109, D13204, doi:10.1029/2003JD004324, 2004.

Crosier, J., Allan, J. D., Coe, H., Bower, K. N., Formenti, P., and Williams, P. I.: Chemical composition of summertime aerosol in the Po Valley (Italy), Northern Adriatic, and Black Sea, Q. J. Roy. Meteorol. Soc., 133, 61-75, 2007.

Cruz, C. N. and Pandis, S. N.: A study of the ability of pure secondary organic aerosol to act as cloud condensation nuclei, Atmos. Environ., 31, 2205-2214, 1997.

Cubison, M. J., Ervens, B., Feingold, G., Docherty, K. S., Ulbrich, I. M., Shields, L., Prather, K., Hering, S., and Jimenez, J. L.: The influence of chemical composition and mixing state of Los Angeles urban aerosol on CCN number and cloud properties, Atmos. Chem. Phys., 8, 5649-5667, doi:10.5194/acp-8-5649-2008, 2008.

Cziczo, D. J., DeMott, P. J., Brock, C., Hudson, P. K., Jesse, B., Kreidenweis, S. M., Prenni, A. J., Schreiner, J., Thomson, D. S., and Murphy, D. M.: A method for single particle mass spectrometry of ice nuclei, Aerosol Sci. Technol., 37, 460-470, 2003.

Decesari, S., Facchini, M. C., Fuzzi, S., McFiggans, G. B., Coe,
H., and Bower, K. N.: The water-soluble organic component of size-segregated aerosol, cloud water and wet depositions from Jeju Island during ACE-Asia, Atmos. Environ., 39, 211-222, doi:10.1016/j.atmosenv.2004.09.049, 2005.

DeMott, P. J., Cziczo, D. J., Prenni, A. J., Murphy, D. M., Kreidenweis, S. M., Thomson, D. S., Borys, R., and Rogers, D. C.: Measurements of the concentration and compsition of nuclei for cirrus formation, Proc. Natl. Acad. Sci., 100, 14655-14660, 2003.

Drewnick, F., Hings, S. S., DeCarlo, P. F., Jayne, J. T., Gonin, M., Fuhrer, K., Weimer, S., Jimenez, J. L., Demerjian, K. L., Borrmann, S., and Worsnop, D. R.: A New Time-of-Flight Aerosol Mass Spectrometer (ToF-AMS) - Instrument Description and First Field Deployment, Aerosol Sci. Technol., 39, 637-658, 2005.

Duplissy, J., DeCarlo, P. F., Dommen, J., Alfarra, M. R., Metzger, A., Barmpadimos, I., Prevot, A. S. H., Weingartner, E., Tritscher, T., Gysel, M., Aiken, A. C., Jimenez, J. L., Canagaratna, M. R., Worsnop, D. R., Collins, D. R., Tomlinson, J., and Baltensperger, U.: Relating hygroscopicity and composition of organic aerosol particulate matter, Atmos. Chem. Phys., 11, 1155-1165, doi:10.5194/acp-11-1155-2011, 2011.

Heintzenberg, J., Okada, K., and Strom, J.: On the composition of non-volatile material in upper tropospheric aerosols and cirrus crystals, Atmos. Res., 41, 81-88, 1996.

Hiranuma, N., Kohn, M., Pekour, M. S., Nelson, D. A., Shilling, J. E., and Cziczo, D. J.: Droplet activation, separation, and compositional analysis: laboratory studies and atmospheric measurements, Atmos. Meas. Tech. Discuss., 4, 691-713, doi:10.5194/amtd-4-691-2011, 2011.

Hutchings, J. W., Robinson, M. S., Mellwraith, H., Triplett Kingston, J., Herckes, P.: The chemistry of intercepted clouds in Northern Arizona during the North American monsoon season, Water Air Soil Pollut., 199, 191-202, doi:10.1007/s11270-0089871-0, 2009.

IPCC (Intergovernmental Panel on Climate Change): Contribution of Working Group I to the Fourth Assessment Report of the Intergovernmental Panel on Climate change, 2007, edited by: Solomon, S., Qin, D., Manning, M., Chen, Z., Marquis, M., Averyt, K. B., Tignor, M., and Miller, H. L., New York, NY, USA, 2007.

Jacobson, M. C., Hansson, H.-C., Noone, K. J., and Charlson, R. J.: Organic atmospheric aerosols: Review and state of the science, Rev. Geophys., 38, 267-294, 2000.

Johnson, G. R., Ristovski, Z. D., D’Anna, B., and Morawska, L.: Hygroscopic behavior of partially volatilized coastal marine aerosols using the volatilization and humidification tandem differential mobility analyzer technique, J. Geophys. Res.-Atmos., 110, D20203, doi:10.1029/2004JD005657, 2005.

Kamphus, M., Ettner-Mahl, M., Klimach, T., Drewnick, F., Keller, L., Cziczo, D. J., Mertes, S., Borrmann, S., and Curtius, J.: Chemical composition of ambient aerosol, ice residues and cloud droplet residues in mixed-phase clouds: single particle analysis during the Cloud and Aerosol Characterization Experiment (CLACE 6), Atmos. Chem. Phys., 10, 8077-8095, doi:10.5194/acp-10-8077-2010, 2010.

Köhler, H.: The nucleus in the growth of hygroscopic droplets, Trans. Farady Soc., 32, 1152-1161, 1936.

Kulkarni, G., Pekour, M., Afchine, A., Murphy, D. M., and Cziczo, D. J.: Comparison of experimental and numerical studies of the 
performance characteristics of a pumped counterflow virtual impactor, Aerosol Sci. Technol., 45, 382-392, 2011.

Middlebrook, A. M., Bahreini, R., Jimenez, J. L., and Canagaratna, M. R.: Evaluation of composition-dependent collection efficiencies for the Aerodyne aerosol mass spectrometer using field data, Aerosol Sci. Technol., in press, 2011.

Noone, K. J., Ogren, J. A., Heintzenberg, J., Charlson, R. J., and Covert, D. S.: Design and calibration of a counterflow virtual impactor for sampling of atmospheric fog and cloud droplets, Aerosol Sci. Technol., 8, 235-244, 1988.

Lance, S., Nenes, A., Mazzoleni, C., Dubey, M. K., Gates, H., Varutbangkul, V., Rissman, T. A., Murphy, S. M., Sorooshian, A., Flagan, R. C., Seinfeld, J. H., Feingold, G., and Jonsson, H. H.: Cloud condensation nuclei activity, closure, and droplet growth kinetic of Houston aerosol during the Gulf of Mexico Atmospheric Composition and Climate Study (GoMAACCS), J. Geophys. Res.-Atmos., 114, D00F15, doi:10.1029/2008JD011699, 2009.

Liou, K. N. and Ou, S. C.: The role of cloud microphysical processes in climate - An assessment from a one-dimensional perspective, J. Geophys. Res.-Atmos., 104, 8095-8111, 1989.

Matthew, B. M., Middlebrook, A. M., and Onasch, T. B.: Collection efficiencies in an Aerodyne aerosol mass spectrometer as a function of particle phase for laboratory generated aerosols, Aerosol Sci. Technol., 42, 884-898, 2008.

Medina, J., Nenes, A., Sotiropoulou, R. E. P., Cottrell, L. D., Ziemba, L. D., Beckman, P. J., and Griffin, R. J.: Cloud condensation nuclei closure during the International Consortium for Atmospheric Research of Transport and Transformation 2004 campaign: Effects of size-resolved composition, J. Geophys. Res., 112, D10S31, doi:10.1029/2006JD007588, 2007.

Ogren, J. A., Heintzenberg, J., and Charlson, R. J.: In-situ sampling of clouds with a droplet to aerosol converter, Geophys. Res. Lett., 12, 121-124, 1985.

Pradeep Kumar, P., Broekhuizen, K., and Abbatt, J. P. D.: Organic acids as cloud condensation nuclei: Laboratory studies of highly soluble and insoluble species, Atmos. Chem. Phys., 3, 509-520, doi:10.5194/acp-3-509-2003, 2003.

Parungo, F., Nagamoto, C., Nolt, I., Dias, M., and Nickerson, E.: Chemical analysis of cloud water collected over Hawaii, J. Geophys. Res.-Oceans, 87, 8805-8810, doi:10.1029/JC087iC11p08805, 1982.

Petters, M. D. and Kreidenweis, S. M.: A single parameter representation of hygroscopic growth and cloud condensation nucleus activity, Atmos. Chem. Phys., 7, 1961-1971, doi:10.5194/acp-71961-2007, 2007.

Quinn, P. K., Bates, T. S., Coffmann, D., Onasch, T. B., Worsnop, D., Baynard, T., de gouw, J. A., Goldan, P. D., Kuster, W. C., Williams, E., Roberts, J. M., Lerner, B., Stohl, A., Pettersson, A., and Lovejoy, E. R.: Impacts of sources and aging on submicrometer aerosol properties in the marine boundary layer across the Gulf of Maine, J. Geophys. Res., 111, D23S36, doi:10.1029/2006JD007582, 2006.

Quinn, P. K., Bates, T. S., Coffman, D. J., and Covert, D. S.: Influence of particle size and chemistry on the cloud nucleating properties of aerosols, Atmos. Chem. Phys., 8, 1029-1042, doi:10.5194/acp-8-1029-2008, 2008.

Raymond, T. M. and Pandis, S. N.: Cloud activation of single-component organic aerosol particles, J. Geophys. Res.,
107(D24), 4787, doi:10.1029/2002JD002159, 2002.

Raymond, T. M. and Pandis, S. N.: Formation of cloud droplets by multicomponent organic particles, J. Geophys. Res., 108(D15), 4469, doi:10.1029/2003JD003503, 2003.

Ruehl, C. R., Chuang, P. Y., and Nenes, A.: How quickly do cloud droplets form on atmospheric particles?, Atmos. Chem. Phys., 8, 1043-1055, doi:10.5194/acp-8-1043-2008, 2008.

Ruehl, C. R., Chuang, P. Y., and Nenes, A.: Distinct CCN activation kinetics above the marine boundary layer along the California coast, Geophys. Res. Lett., 36, L15814, doi:10.1029/2009GL038839, 2009.

Saxena, P. and Hildemann, L. M.: Water-soluble organics in atmospheric particles: A critical review of the literature and application of thermodynamics to identify candidate compounds, J. Atmos. Chem., 24, 57-109, 1996.

Shantz, N. C., Leaitch, W. R., and Caffrey, P. F: Effect of organics of low solubility on the growth rate of cloud droplets, J. Geophys. Res.-Atmos., 108, 4168-4176, 2003.

Shantz, N. C., Chang, R. Y.-W., Slowik, J. G., Vlasenko, A., Abbatt, J. P. D., and Leaitch, W. R.: Slower CCN growth kinetics of anthropogenic aerosol compared to biogenic aerosol observed at a rural site, Atmos. Chem. Phys., 10, 299-312, doi:10.5194/acp10-299-2010, 2010.

Slowik, J. G., Stroud, C., Bottenheim, J. W., Brickell, P. C., Chang, R. Y.-W., Liggio, J., Makar, P. A., Martin, R. V., Moran, M. D., Shantz, N. C., Sjostedt, S. J., van Donkelaar, A., Vlasenko, A., Wiebe, H. A., Xia, A. G., Zhang, J., Leaitch, W. R., and Abbatt, J. P. D.: Characterization of a large biogenic secondary organic aerosol event from eastern Canadian forests, Atmos. Chem. Phys., 10, 2825-2845, doi:10.5194/acp-10-2825-2010, 2010.

Solomon, S., Qin, D., Manning, M., Chen, Z., Marquis, M., Averyt, K. B., Tignor, M., and Miller, H. (Eds): IPCC, 2007: Summary for Policymakers, Climate Change 2007: The Physical Science Basis. Contribution of Working Group I to the Fourth Assessment Report of the Intergovernmental Panel on Climate Change, Cambridge University Press, New York, 2007.

Twohy, C. H. and Gandrud, B. W.: Electron microscope analysis of residual particles from aircraft contrails, Geophys. Res. Lett., 25, 1359-1362, 1998.

Twomey, S.: Influence of pollution on the short-wave albedo of clouds, J. Atmos. Sci., 34, 1149-1152, 1977.

Twomey, S. A., Peipgrass, M., and Wolfe, T.: An assessment of the impact of pollution on the global albedo, Tellus, 36B, 356-366, 1984.

Vlasenko, A., Slowik, J. G., Bottenheim, J. W., Brickell, P. C., Chang, R. Y.-W., Macdonald, A. M., Shantz, N. C., Sjostedt, S. J., Wiebe, H. A., Leaitch, W. R., and Abbatt, J. P. D.: Measurements of VOCs by proton transfer reaction mass spectrometry at a rural Ontario site: Sources and correlation to aerosol composition, J. Geophys. Res., 114, D21305, doi:10.1029/2009JD12025, 2009.

Zhang, Q., Worsnop, D. R., Canagaratna, M. R., and Jimenez, J. L.: Hydrocarbon-like and oxygenated organic aerosols in Pittsburgh: insights into sources and processes of organic aerosols, Atmos. Chem. Phys., 5, 3289-3311, doi:10.5194/acp-5-32892005, 2005.

Zobrist, B., Marcolli, C., Pedernera, D. A., and Koop, T.: Do atmospheric aerosols form glasses?, Atmos. Chem. Phys., 8, 52215244, doi:10.5194/acp-8-5221-2008, 2008. 